\title{
Clinical Evaluation of the Effect of Implant-Supported and Implant Retained Distal Extension Removable Partial Dentures on the Supporting Structures
}

\author{
Ragia Saad Mohamed Kotb ${ }^{1 *}$, Ahmed Gamal Ahmed Hassan², Emad Mohamed Tolba M. Agamy ${ }^{3}$, Gehan Fekry Mohamed ${ }^{4}$ \\ ${ }^{1}$ Department of Prosthodontics, Faculty of Dentistry, Alexandria University, Alexandria, Egypt; ${ }^{2}$ Department of Prosthodontics, \\ Faculty of Dentistry, Minia University, Minya, Egypt; ${ }^{3}$ Department of Prosthodontics, Vice Dean for Education and Student \\ Affairs, Faculty of Dentistry, Minia University, Minya, Egypt; ${ }^{4}$ Department of Prosthodontics, Kantara University, Qantara, Egypt
}

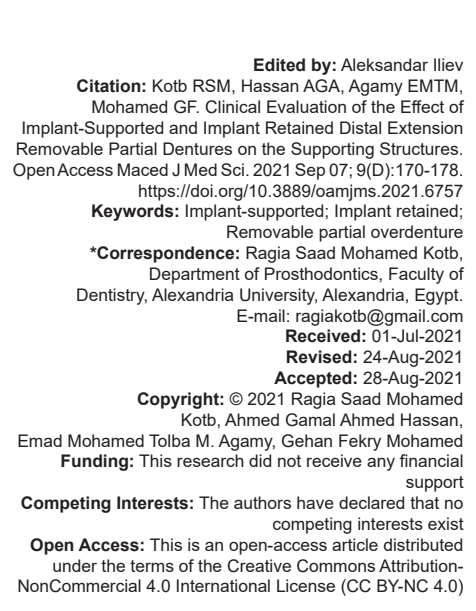

Introduction

Removable dentures remain an essential prosthetic consideration in many conditions of oral rehabilitation, especially when restoring edentulous spaces posterior to the anterior remaining teeth [1].

Kennedy class I presents challenges for clinicians, as these dentures require support from the teeth, the mucosa and the underlying residual alveolar ridges. In particular, the distal extension removable partial denture (RPD) is subjected to vertical, horizontal and torsional forces that may have adverse effects during functional and para-functional activities [2].

The problems could be attributed to the absence of the posterior abutment [3]. Since the difference in displacement between the mucosa and the periodontal ligament of last standing abutment was estimated to be up to 25 times [4]. Consequently, when functional pressure is applied to the distal extension base RPD, the resultant forces are extremely damaging to the abutment teeth and must be controlled if clinical treatment is to be successful [5].

The use of distal implants to support and retain RPDs has been reported in the literature to minimize dislodgement, improve aesthetics and mastication as well as increase patient satisfaction in cost-effective manner [6], [7], [8].

The use of dental implant as a distal abutment can convert a distal extension RPD from a tooth and tissue-supported prosthesis to a tooth and implantsupported and retained prosthesis. A posteriorly placed implant provides a definite stop and stability and eliminates the problems often associated with a tooth and tissue-supported distal extension RPD [9], [10].

Dental implants reported in many studies a high success rate when they are combined with a partial denture in free end cases, especially in the mandible which can be a suitable treatment option because the pressure applied to tooth abutments can be decreased [11]. 
An implant-retained RPD provides patients with unique service and benefits not possible with more conventional treatment options [12]. It has been noted that the placement of dental implants in an edentulous space provides the biologic advantage of reducing bone resorption, also provides distinct biomechanical advantage in reducing the effect of the reciprocal arm of a conventional RPD and improving the fulcrum line position, as well as offering superior retention and elimination of unaesthetic clasps in the aesthetic zone. Adding flange on such prosthesis also allows for restoring facial esthetics and extraoral soft tissue support lost from advanced ridge resorption [13].

Combination of natural tooth and implantsupported RPD was reported. This design of connection allows stress control on the fixtures and natural abutments, provides strength, esthetics, fulfilling patients' desire and increasing the long-term prognosis for the remaining teeth. The only disadvantages are that it is "removable" and some patients may not tolerate this type of prosthesis and the cost factor [14].

Several authors have been debated to connect natural teeth and implants together in a fixed partial denture [15], [16], [17], [18], fears of possible negative effects resulting from splinting natural teeth with osseointegrated implants have always played a superior role in not accepting this option as a mode of treatment and the majority of implant dentists worldwide avoid splinting the two in a fixed prosthesis [19].

Using ball attachment and O-ring to retain mandibular RPD on a bilateral single molar implants in cases of Kennedy class I cases helped to support and retain the mandibular RPD and present a cost-effective treatment [10].

The dome-type attachments have the function to allow displacement or rotation of the overdenture during function [20].

The aim of the study was to compare between two types of implant superstructures, namely dome and ball attachments regarding their effect on the longevity of both implants and natural abutments in cases restored by RPDs.

\section{Subjects and Methods}

\section{The study and sample size}

The study was a comparative study. Superstructures were randomly distributed for patients in both groups. Sample size was calculated to be 12 implants in each group.

\section{Patient selection}

Twelve patients with partially edentulous lower arch Kennedy's class I were selected from the outpatient clinic, Prosthodontics Department, Faculty of Dentistry, Minia University. All the patients had their first or second premolar as posterior abutments, had full dentition in the maxillary arch, free from any systemic disorder that may affect dental implant rigid fixation to the bone and with average ridge form and height to receive implant of (diameter $3.7 \mathrm{~mm}$ and length $8.5 \mathrm{~mm}$. The patients were informed by all procedures of our study. Only motivated patients who showed cooperation participated in the study and an informed consent were assigned, also the approval of Research Ethics Committee of the Faculty of Dentistry Minia University was obtained.

\section{Clinical procedures}

Stage 1: Construction of acrylic partial denture for the lower arch.

Each patient had received lower acrylic partial denture with conventional method.

Stage 2: Fabrication of surgical guide and radiographic examination.

A customized surgical guide was fabricated using CAD/CAM technology through the data obtained from the cone-beam computed tomography (CBCT), captured images by CBCT were imported into viewing software then sent for fabrication of the guide.

\section{Stage 3: Surgical procedure}

The surgical procedures were performed in one step under aseptic conditions. The implants were located at the second molar site in the edentulous area of the mandible. All patients were anaesthetized by local nerve block and infiltration at the site of the surgical field. The incision was made at the crest of the ridge, crestal flap was achieved by a sharp scalpel number 15 blades. The scalpel was pressed firmly to bone and the incision was made once for clean-cut or by tissue punch. Pilot drill was pointed down through the hole reaching down to the alveolar bone and punching it to make a point that acts as a guide for drilling. The sterilized surgical stent was placed securely in the oral cavity with its hole corresponding to the planned implant position. Drilling was done through the stent's hole with light intermittent finger pressure using sterile saline solution irrigation. Drilling was performed starting with the pilot drill $(2.3 \mathrm{~mm})$ in diameter then intermediate drill $(2.8 \mathrm{~mm} \mathrm{D})$ was used and driven to the full depth of the planned implant, and finally with $(3.5 \mathrm{~mm} \mathrm{D})$. The paralleling rod was inserted into the drill hole to make sure that the implant was in its right position. The implant was removed from the sterile pack with the fixture mount and was inserted to the osteotomy till the implant collar by handpiece then manual using ratchet wrench. A surgical cover screw corresponding to the 
diameter of the implant was placed and tightened into position with hand screwdriver. A hand debridement and irrigation of the surgical site was carried out. The flap was repositioned around the implant and sutured by interrupted sutures using 3-0 silk sutures. Surgical technique was repeated for the other side either by surgical flap or using tissue punch.

Stage 4: Prosthetic procedure

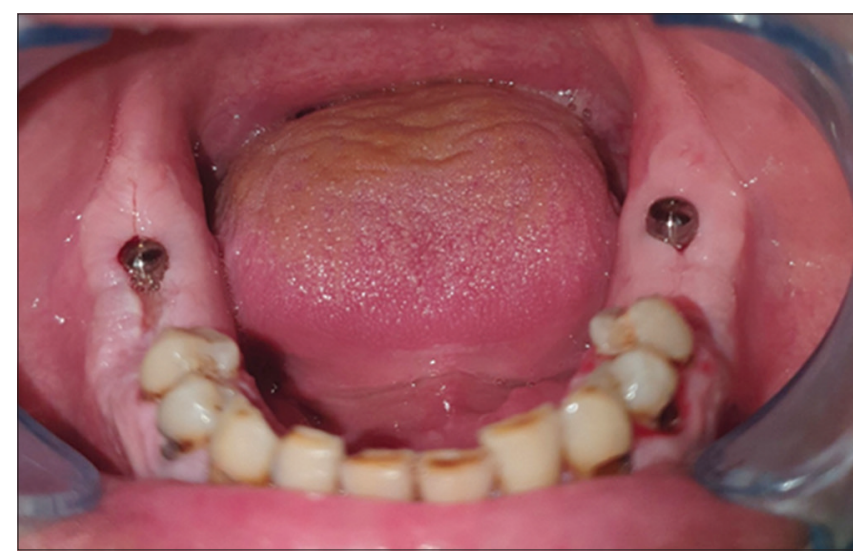

Figure 1: Dome shaped abutment for group I

\section{Mouth preparations}

All patients had to complete phase I therapy including supra and subgingival scaling, root planning and curettage. Proper oral hygiene instructions including the appropriate brushing technique and interdental cleaning procedures were implemented. This phase also included minor occlusal adjustments when needed, occlusal analysis and correction for occlusal reconstruction were made either by selective grinding, obturation of carious lesions, crowning or removal of overhanging margins and uncovering the implant by removing the tissue above it using tissue punch. The surgical cover screw was removed using the screwdriver and the implant abutment was screwed into the implant. Inside the patient mouth for Group I they received dome-shaped abutment, while Group II received ball abutment (Figures 1 and 2 ).

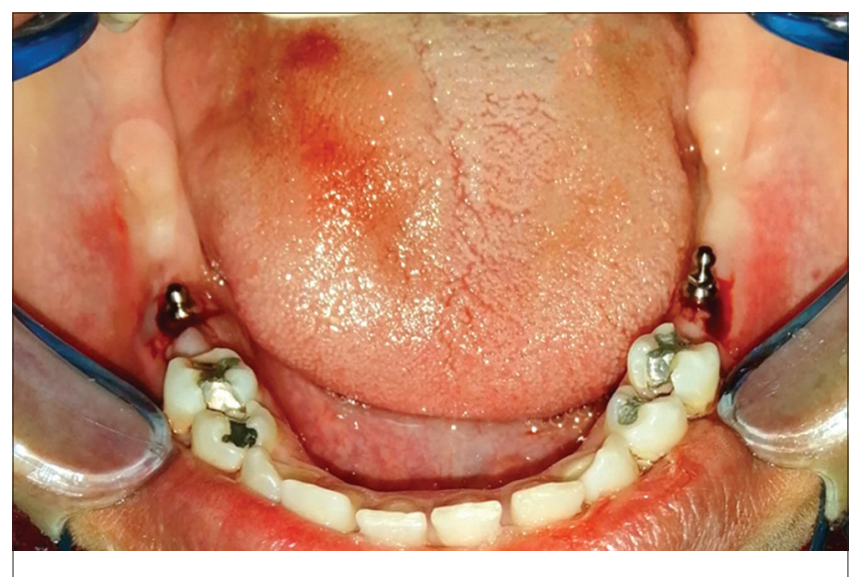

Figure 2: Ball abutment for group II
The mouth preparations were made as the following:

- Mesial occlusal rest seat for the $1^{\text {st }}$ or $2^{\text {nd }}$ premolar (the main abutment) adjacent to the edentulous area

- $\quad$ Canine rest or distal occlusal rest seat adjacent to the main abutment

Both groups were included for constructing the conventional Cobalt-Chromium RPD after the healing period with the same design RPD with the conventional way. Maxillary and mandibular preliminary impressions, final impression, duplication of the master cast was performed to obtain a refractory model for waxing up the partial overdenture framework., try in of metal framework (Figures 3 and 4) Jaw relation registration, partial overdenture try in was made with normal acrylic teeth, flasking, finishing and polishing then insertion.

- $\quad$ Mesial occlusal rest for the $1^{\text {st }}$ or $2^{\text {nd }}$ premolar (the main abutment) adjacent to the edentulous area

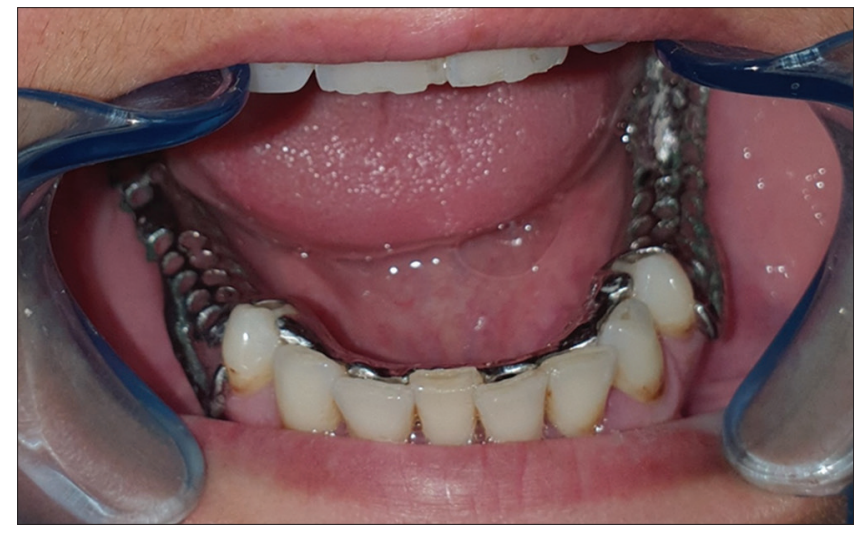

Figure 3: Metal framework try in for group I

- Lingual plate major connector

- Cingulum rests on mandibular canines or distal occlusal rests adjacent to the abutment. For Group I with dome-shaped abutment, the secondary coping is a part of the metal framework, (Figure 5), whereas in Group II the $O$ ring housing is attached to the ball abutment and connected to the framework by direct

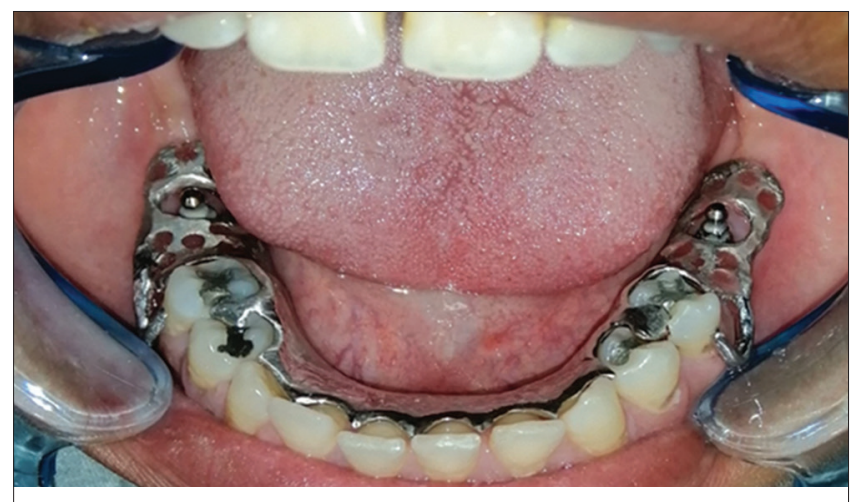

Figure 4: Metal framework try in for group II 
pick up technique using monomer free- cold cure acrylic resin material (Figure 6) Partial overdenture was inserted into the patient's mouth and was checked for retention, stability and support. Instructions were given to the patient about how to use and clean the partial denture.

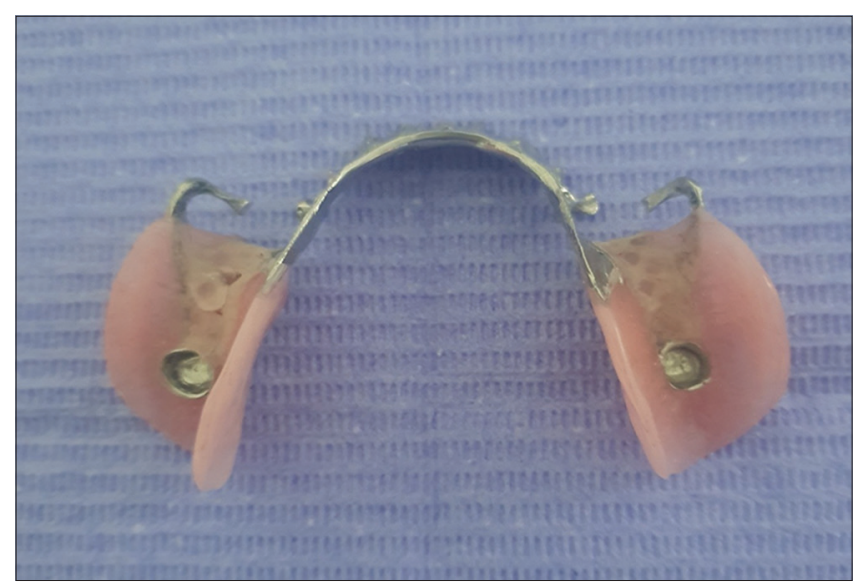

Figure 5: The secondary coping is a part of the metal frame work for Gp. I

\section{Clinical evaluation}

Each case was evaluated clinically at the time of denture insertion, 3, 6 and 12 months later. Clinical evaluation included assessment modified gingival index, probing depth around the main abutment and implant abutments.

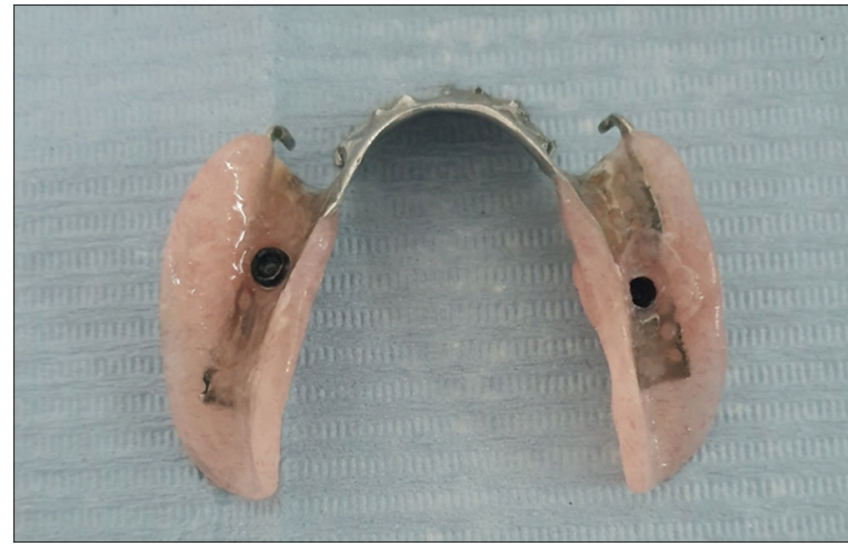

Figure 6: The $O$ ring connected to the frame work by direct pick up technique using selfcure- cold cure acrylic resin material for gp. II

\section{Modified gingival index}

Modified Gingival index was measured for main abutments and implant in Groups I and II (Table 1 and 2). according to Lobene and Weatherford (1986) [21] for implants in Group I and II. The circumference of the gingival margin was divided into buccal, mesiobuccal, distobuccal, and lingual [22], [23]. Each of them was scored from 0 to 4 according to the following:

\section{$0=$ $1=$ \\ Absence of inflammation, normal gingival. \\ Mild inflammation, slight color change, little change in texture of any portion of, but not entire, marginal, or papillary gingival unit (localized). \\ Mild inflammation, slight color change, little change in texture involving the entire or papillary gingival unit (generalized). \\ $3=$ Moderate inflammation, redness, and edema. Severe inflammation, marked redness, edema, ulceration, and spontaneous bleeding.}

\section{Probing depth}

It refers to the distance from the gingival margin to the bottom of clinical pocket according to Glavind and Loe 1967 [24]. Moreover, gingival sulcus depth around implants [25].

Probing depth was evaluated using pressuresensitive color coded plastic probe* with perceptible click and divided into 3/5/7/10 $\mathrm{mm}$.

a. Periodontal probing depth for the main abutment (Figure 7 and Table 3).

b. Peri-implant probing depth around implant (Figure 8 and Table 4).

The measurements were taken from each of the four axial surfaces of main abutments buccal, mesiobuccal, distobuccal and lingual, for Groups I and II. Peri-implant probing depths were measured according to Atassi [17] at four surfaces of implants:

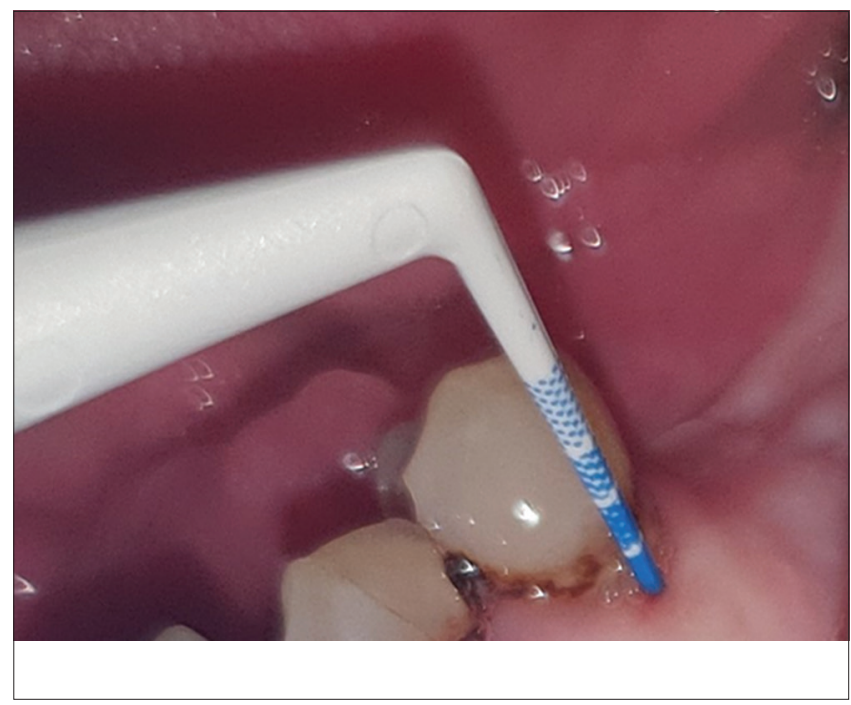

Figure 7: Periodontal probing depth for the main abutment

Buccal, mesiobuccal, distobuccal and lingual; and parallel to the long axis after taking the implant collar as a reference point during measuring.

\section{Radiographic evaluation of marginal bone}

loss

For both groups, marginal bone level around the implants was examined using CBCT. Marginal bone level 


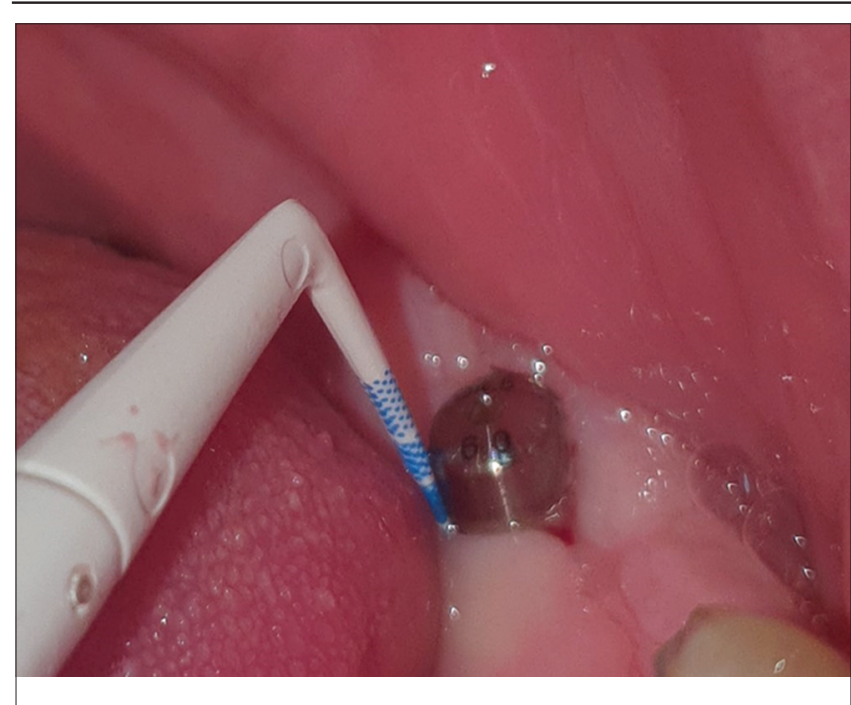

Figure 8: Peri-implant probing depth around implant

was measured using OnDemand3D Application software (Sordex-Scanora $^{\circledR} 3 \mathrm{D}$ ). The distance from the marginal bone to the apex of the implant was calculated in millimetres using straight line tool of the system. The mesial and distal bone heights were measured on the sagittal view screen, while the buccal and lingual bone heights were measured on the coronal view screen using the linear assessment OnDemand3D software. The mean value of readings was taken, tabulated and statistically analyzed (Table 5).

\section{Results and Statistical Analysis}

Data were fed to the computer using IBM SPSS software package version 24.0. Qualitative data were described using number and percentage. Comparison between different groups regarding categorical variables was tested using Chi-square test.

Quantitative data were described using mean and standard deviation for normally distributed data while abnormally distributed data were expressed using median, minimum and maximum. For normally distributed data, comparison between two independent population was done using independent t-test while more than two population were analyzed F-test (ANOVA) to be used. The results of this study were represented by tables. The significant level was set at $P \leq 0.05$.

The type of that study is randomized controlled trial with calculated samples. Randomization in this study the investigators randomly distribute the patients with the two different types of abutments before any surgical procedures.

\section{Discussion}

Selection of implant-retained overdenture treatment for the posterior edentulous mandible can
Table 1: Modified gingival index for abutment teeth in Group I (dome-shaped abutment) and II (O-ring attachment) at different period of follow-up

\begin{tabular}{|c|c|c|c|c|c|c|c|c|}
\hline \multirow[t]{2}{*}{ Group I } & \multicolumn{2}{|c|}{ Insertion } & \multicolumn{2}{|c|}{3 months } & \multicolumn{2}{|c|}{6 months } & \multicolumn{2}{|c|}{12 months } \\
\hline & No & $\%$ & No & $\%$ & No & $\%$ & No & $\%$ \\
\hline Grade 0 & 12 & 100.0 & 10 & 83.33 & 12 & 100.0 & 12 & 100.0 \\
\hline Grade 1 & 0 & 0.0 & 2 & 16.67 & 0 & 0.0 & 0 & 0.0 \\
\hline Grade 2 & 0 & 0.0 & 0 & 0.0 & 0 & 0.0 & 0 & 0.0 \\
\hline Grade 3 & 0 & 0.0 & 0 & 0.0 & 0 & 0.0 & 0 & 0.0 \\
\hline Grade 4 & 0 & 0.0 & 0 & 0.0 & 0 & 0.0 & 0 & 0.0 \\
\hline \multirow{2}{*}{\multicolumn{3}{|c|}{$\begin{array}{l}\text { P1 } \\
\text { Group II }\end{array}$}} & \multicolumn{2}{|c|}{0.365 N.S. } & \multicolumn{2}{|c|}{1.00 N.S. } & \multicolumn{2}{|c|}{1.00 N.S. } \\
\hline & \multicolumn{8}{|c|}{ Group II } \\
\hline Grade 0 & 12 & 100.0 & 8 & 66.67 & 8 & 66.67 & 10 & 83.33 \\
\hline Grade 1 & 0 & 0.0 & 4 & 33.33 & 2 & 16.67 & 2 & 16.67 \\
\hline Grade 2 & 0 & 0.0 & 0 & 0.0 & 2 & 16.67 & 0 & 0.0 \\
\hline Grade 3 & 0 & 0.0 & 0 & 0.0 & 0 & 0.0 & 0 & 0.0 \\
\hline Grade 4 & 0 & 0.0 & 0 & 0.0 & 0 & 0.0 & 0 & 0.0 \\
\hline $\mathrm{P} 1$ & & & \multicolumn{2}{|c|}{$0.042^{*}$} & \multicolumn{2}{|c|}{$0.040^{*}$} & \multicolumn{2}{|c|}{0.365 N.S. } \\
\hline P2 & \multicolumn{2}{|c|}{1.00 N.S. } & 0.45 & & 0.40 & & 0.36 & \\
\hline
\end{tabular}

Table 2: Modified Gingival index in Group I (dome-shaped abutment) and II (O-ring attachment) for implant at different period of follow up

\begin{tabular}{|c|c|c|c|c|c|c|c|c|}
\hline \multirow[t]{2}{*}{ Group I } & \multicolumn{2}{|c|}{ Insertion } & \multicolumn{2}{|c|}{3 months } & \multicolumn{2}{|c|}{6 months } & \multicolumn{2}{|c|}{12 months } \\
\hline & No & $\%$ & No & $\%$ & No & $\%$ & No & $\%$ \\
\hline Grade 0 & 10 & 83.3 & 10 & 83.3 & 12 & 100.0 & 12 & 100.0 \\
\hline Grade 1 & 2 & 16.7 & 0 & 0.0 & 0 & 0.0 & 0 & 0.0 \\
\hline Grade 2 & 0 & 0.0 & 2 & 16.7 & 0 & 0.0 & 0 & 0.0 \\
\hline Grade 3 & 0 & 0.0 & 0 & 0.0 & 0 & 0.0 & 0 & 0.0 \\
\hline Grade 4 & 0 & 0.0 & 0 & 0.0 & 0 & 0.0 & 0 & 0.0 \\
\hline \multirow{2}{*}{\multicolumn{3}{|c|}{$\begin{array}{l}\text { P1 } \\
\text { P }\end{array}$}} & \multicolumn{2}{|c|}{0.108 N.S. } & \multicolumn{2}{|c|}{0.365 N.S. } & \multicolumn{2}{|c|}{1.00 N.S. } \\
\hline & \multicolumn{8}{|c|}{ Group II } \\
\hline Grade 0 & 10 & 83.3 & 10 & 83.3 & 10 & 83.3 & 10 & 83.3 \\
\hline Grade 1 & 2 & 16.7 & 2 & 16.7 & 0 & 0.0 & 2 & 16.7 \\
\hline Grade 2 & 0 & 0.0 & 0 & 0.0 & 2 & 16.7 & 0 & 0.0 \\
\hline Grade 3 & 0 & 0.0 & 0 & 0.0 & 0 & 0.0 & 0 & 0.0 \\
\hline Grade 4 & 0 & 0.0 & 0 & 0.0 & 0 & 0.0 & 0 & 0.0 \\
\hline $\mathrm{P} 1$ & \multirow{2}{*}{\multicolumn{2}{|c|}{1.00 N.S. }} & \multirow{2}{*}{\multicolumn{2}{|c|}{$\begin{array}{l}1.00 \text { N.S. } \\
0.108 \text { N.S. }\end{array}$}} & \multirow{2}{*}{\multicolumn{2}{|c|}{$\begin{array}{l}0.108 \text { N.S. } \\
0.211 \text { N.S. }\end{array}$}} & \multicolumn{2}{|c|}{1.00 N.S. } \\
\hline P2 & & & & & & & 0.36 & J.S. \\
\hline
\end{tabular}

significant. p value was calculated by using Chi-square test

provide both the patient and clinician with several advantages [26]. Mandibular implant-retained overdenture treatment has significantly increased the scores for retention and stability of the denture, masticatory function and general denture satisfaction. Furthermore, it may have favorable psychological and social effects on the patient [27]. Furthermore, the pressure applied to tooth abutments can be decreased as such; however, implant-abutment tooth attachment type is a matter of discussion [11].

Table 3: Probing depth in Group I and II at different periods of follow-up

\begin{tabular}{lllll}
\hline Abutment teeth & Insertion & 3 months & 6 months & 12 months \\
\hline Group I & & & & \\
Rang & $1.5-2.3$ & $1.8-2.5$ & $2.2-2.5$ & $2.6-3.5$ \\
Mean & 1.78 & 2.09 & 2.35 & 2.94 \\
SD & 0.32 & 0.33 & 0.16 & 0.39 \\
P1 & & 0.069 & $0.031^{*}$ & $0.022^{*}$ \\
Group II & & & & \\
Rang & $1.5-2.3$ & $2.1-2.5$ & $2.1-2.8$ & $2.1-3$ \\
Mean & 2.02 & 2.41 & 2.41 & 2.77 \\
SD & 0.28 & 0.14 & 0.21 & 0.27 \\
P1 & & 0.113 & $0.044^{*}$ & $0.027^{*}$ \\
P2 & 0.069 & 0.075 & 0.311 & 0.254 \\
\hline P1 comparison between time of insertion with other time of follow up in the same group. P2 comparison \\
between the two groups at the same time. p was significant if < 0.05 . *Significant difference. N.S.: Not \\
significant. P1 value was calculated by using ANOVA test. P2 value was calculated by using student t-test
\end{tabular}

In rigid attachments, higher stress accumulation can cause higher bone loss and increase the frequency 
of prosthetic complications such as fatigue fracture and screw loosening compared to resilient attachments. In non-rigid attachments may cause dental intrusion. Intrusion of tooth abutment decreases support and increases cantilever stresses in implants and the supporting bone [28].

However, in the attachment of natural teeth and implant by a RPD, intrusion of natural teeth does not seem to be problematic because permanent attachment of the prosthesis to tooth and implant does not exist [29].

Implant used in this study was placed into the second molar area, to avoid the posterior rotation of the partial overdenture on the implant's abutment as a fulcrum [30], [31].

Two-stage surgery for the implant placement primarily have been considered by many authors for two reasons; to prevent early failure due to loading and to prevent infection [32], [33]. The number of stages for implant placement depends on the primary stability of the implant and the quality of the bone.

Choosing dome-shaped abutment was to reduce the load on the implant by permitting slight rotational movements [34]. O-ring ball abutment is an excellent method for increasing the retention and stability of such dentures and has several advantages, including ease of use, hygiene, and maintenance, and low cost [35].

Success criteria of osseointegration included: no clinical mobility; no peri-implant radiolucency or infection; no complaints of pain, neuropathy, or paresthesia; and crestal bone loss that does not exceed $1.5 \mathrm{~mm}$ at the end of the $1^{\text {st }}$ year [36].

Accordingly, patients were scheduled for follow-up at partial denture insertion after 3, 6, and 12 clinically compare modified gingival index, probing depth around the abutment teeth and implant, as well as evaluation of marginal bone loss around the implant radiographically by using $\mathrm{CBCT}$.

Measurements of periodontal probing depths around main abutments and peri-implants probing depths were made using the pressure-sensitive probe with a perceptible (click), to eliminate excessive forces generated by using conventional types [25], [37].

The results of the clinical evaluation of the present study of modified gingival index for abutment teeth demonstrated a non-significant change in all follow-up periods in group I. Despite continuous patient motivation for oral hygiene measures for all patients in both groups, Group II showed significant decrease in the percentages from grade 0 after 3 and 6 months this could be due to careless handling for oral hygiene measure in this group. These results agree with result conducted by Augustin et al., that found there are significant differences between study and control groups regarding gingival index, they attributed the cause due
Table 4: Peri-implant probing depth in Group I and II at different periods of follow-up

\begin{tabular}{lllll}
\hline Abutment teeth & Insertion & 3 months & 6 months & 12 months \\
\hline Group I & & & & \\
Rang & $1.5-2.4$ & $1.8-2.5$ & $2.2-2.5$ & $2.1-3.5$ \\
Mean & 1.79 & 2.03 & 2.40 & 2.51 \\
SD & 0.27 & 0.29 & 0.18 & 0.45 \\
P1 & & 0.107 & $0.038^{*}$ & $0.034^{*}$ \\
Group II & $1.5-2.3$ & $2.1-2.6$ & $2.1-2.8$ & $2.5-3.1$ \\
Rang & 2.08 & 2.32 & 2.47 & 2.88 \\
Mean & 0.21 & 0.16 & 0.26 & 0.32 \\
SD & & 0.211 & 0.072 & $0.042^{*}$ \\
P1 & 0.103 & 0.096 & 0.56 & 0.101 \\
P2 & & &
\end{tabular}

to poor oral care [38]. Continuous and routine follow-up of the implant patient with periodic assessment of plaque and calculus for both groups, after 12 months there was non-significant change from time of insertion.

The comparison between the results of modified gingival index for implant between the two groups showed a non-significant difference at any given period of follow-up. This result was in agreement with Alam-Eldeen [39], who concluded that regardless the type of the retainer used with natural abutments, gingival index had no significant differences effect on implants and natural abutment teeth.

Table 5: Results of radiographic evaluation Marginal Bone Loss in both coronal and sagittal view in two studied groups at different periods of follow-up

\begin{tabular}{lllll}
\hline & Insertion & 3 months & 6 months & 12 months \\
\hline Group I & & & & \\
Rang & $0.0-0.0$ & $0.0-0.5$ & $0.0-1.5$ & $1.0-2.5$ \\
Mean & 0.0 & 0.2 & 0.7 & 1.6 \\
SD & 0.0 & 0.2 & 0.6 & 0.6 \\
P1 & & $0.026^{*}$ & $0.011^{*}$ & $0.001^{*}$ \\
Group II & & & & \\
Rang & $0.0-0.0$ & $0.0-2.0$ & $0.0-2.2$ & $1.0-2.5$ \\
Mean & 0.0 & 0.8 & 1.2 & 1.7 \\
SD & 0.0 & 0.8 & 1.0 & 0.6 \\
P1 & & $0.001^{*}$ & $0.001^{*}$ & $0.001^{*}$ \\
P2 & - & $0.013^{*}$ & $0.013^{*}$ & 0.211 \\
\hline
\end{tabular}

Furthermore, this result was in agreement with Saleh [40], who study the effect of two different clasps, Aker clasp and reverse Aker clasp on tissue health around abutment teeth and implants assisting mandibular bilateral removable partial overdenture, the results were no statistically significant differences between results in regard oral tissue health around the abutment teeth and implants located in the first molar area.

Results of clinical evaluation of probing depth of abutment teeth for both groups, there was insignificant increase in probing depth after 3 months while there was significant increase in 6 and 12 months follow-up periods, there was no significant difference between the two groups at different periods of follow-up.

A significant increase in the measured probing depth of abutments in both groups overdentures was detected throughout the study period, that was shown., this change is considered within the normal reported range of change in probing depth $(0.5-3 \mathrm{~mm})$ [41].

These results agreed with Brill et al that stated that increase in probing depth could be correlated 
to alteration in the oral ecology and to the stresses produced by introducing partial overdentures to the oral cavity [42].

Results of clinical evaluation of peri-implant Probing depth for Group I showed that there was insignificant increase in peri-implant probing depth after 3 months, while there was significant increase after 6 and 12 months in comparison to time of insertion. For Group II there was insignificant increase after 3 and 6 months, while there was significant increase after 12 months.

While comparing the results of both groups together there was insignificant difference regarding peri-implant probing depth at different period of follow up. Group I showed that peri-implant probing depth was less insignificantly than Group II. This may be due to difficulty to obtain proper oral hygiene and more plaque accumulation in ball abutment (Group II) than dome-shaped abutment in Group I. Several studies have indicated that successful implants allow probe penetration of approximately $3 \mathrm{~mm}$ (Nishimura et al.; 1997) [43].

Authors concluded that increased pocket depth could be correlated with a higher degree of inflammation of the peri-implant mucosa [44] but not necessarily with peri-implant bone loss [45].

Results of radiographic evaluation of marginal bone loss for both groups showed there was a significant increase in all periods of follow-up, while when comparing the two groups together there were significant differences after 3 and 6 months, where Group II implant-retained group with ball abutment showed significant increase in mean marginal bone loss than Group I the supported group with domeshaped abutment this may be related to the presence of space between the components of the resilient ball attachment, which may permit free vertical rotation of the overdenture during function with concentration of diverse forces on the residual ridge and the implant. This may be also attributed to that the presence of effective vertical implant support that may decrease the rotation potential of denture base during functional loading [46], [47], [12], our results agreed with Abdou ELsyad who stated that implant-supported partial overdentures appear to be associated with reduced posterior mandibular ridge resorption when compared to implant-retained partial overdentures [48].

The marginal bone loss was statistically significant, after 12 months in both groups and insignificant between both groups. Mitrani et al., suggested that any mechanical wear may occur at the interface between the implant and the denture base will allow the opportunity for the rotation potential to occur, consequently, the implant overloading may occur during function this will lead to marginal bone resorption in both groups [8], [49].

\section{Conclusion}

Within the limitations of this study, the following conclusions could be drawn:

- $\quad$ The use of dome-shaped abutment or ball and O-ring attachment have similar effects on natural abutments and implants in Kennedy class I mandibular situations

There are no significant differences between the two groups on, the modified gingival index, or the increase of probing depth around the natural abutments or dental implants in such cases

- $\quad$ Significant increase in marginal bone loss in group II implant-retained with ball abutment than Group I implant-supported with domeshaped abutment after 3 and 6 months of denture insertion.

\section{References}

1. Giffin KM. Solving the distal extension removable partial denture base movement dilemma: A clinical report. J Prosthet Dent. 1996;76(4):347-49. https://doi.org/10.1016/ s0022-3913(96)90536-3

PMid:8897288

2. Starr NL. The distal extension case: An alternative restorative design for implant prosthetics. Int $\mathrm{J}$ Periodontics Restorative Dent. 2001;21(1):61-7.

PMid:11829037

3. Fahmy A, Abuelroos EM, Nada MM. Effect of using attachment on implant supported distal extension lower partial overdentures. Cairo Dent J. 2008;24(1):1-10.

4. Ishii OA, Nagare I. Longitudinal study on torque transmitted from a denture base to abutment tooth of a distal extension removable partial denture with circumferential clasp. J Oral Rehabil. 1992;19(3):245-52. https://doi.org/10.1111/j.1365-2842.1992. tb01099.x

PMid:1500968

5. Phoenix RD, Cagna DR, Defreest CF. Stewart's Clinica Removable Partial Prosthodontics. $4^{\text {th }}$ ed. United Kingdom: Quintessence Publishing Co, Inc.; 2008. p. 101-18.

6. Kuzmanovic DV, Payne AG, Purton DG. Distal implants to modify the Kennedy classification of a removable partial denture: A clinical report. J Prosthet Dent. 2004;92(1):8-11. https://doi. org/10.1016/j.prosdent.2004.04.010

PMid:15232557

7. Turkyilmaz I. Use of distal implants to support and increase retention of a removable partial denture: A case report. J Calif Dent Assoc. 2009;75(9):655-8.

PMid:19900356

8. Shahmiri RA, Atieh MA. Mandibular Kennedy class I implant-tooth-borne removable partial denture: A systematic review. J Oral Rehabil. 2010;37(3):225-34. https://doi. org/10.1111/j.1365-2842.2009.02044.x

PMid:20050984

9. Carr AB, Brown DT. McCracken's Removable Partial 
Prosthodontics. $12^{\text {th }}$ ed. St Louis: CV Mosby; 2011. p. 24.

10. Ball D. Attachment and O-ring to retain mandibular removable partial denture. J Prosthet Dent. 2004;92:8-11.

11. Cho GC, Chee WW. Apparent intrusion of natural teeth under an implant-supported prosthesis: A clinical report. J Prosthet Dent. 1992;68(1):3-5. https://doi.org/10.1016/0022-3913(92)90274-e PMid:1403915

12. Mijiritsky E. Implants in conjunction with removable partial dentures: A literature review. Implant Dent. 2007;16(2):146-54. https://doi.org/10.1097/id.0b013e3180500b2c

PMid: 17563505

13. Kordatzis K, Wright PS, Meijer HJ. Posterior mandibular residual ridge resorption in patients with conventional denture and implant overdentures. Int $\mathrm{J}$ Oral Maxillofac Implants. 2003;18(3):447-52.

PMid: 12814322

14. Ganz S. Combination natural tooth and implant- borne removable partial denture. A clinical report. J Prosthet Dent. 1991;66(1):1-5. https://doi.org/10.1016/0022-3913(91)90341-s PMid:1941661

15. Van Steenberghe D. Retrospective multi-centre evaluation of the survival rate osseointegrated fixtures supporting fixed partial prostheses in the treatment of partial edentulism. J Prosthet Dent. 1989;61(2):217-23. https://doi. org/10.1016/0022-3913(89)90378-8

PMid:2654366

16. Balshi TJ. Advantages and disadvantages of linking implants to the natural dentition. Oral Maxillofac Surg Clin North Am. 1991;3(4):945-63. https://doi.org/10.1016/ s1042-3699(20)30559-8

17. Cavicchia F, Bravi F. Free standing vs. Tooth-connected implant supported fixed partial restorations: A comparative retrospective clinical study of the prosthetic results. Int $\mathrm{J}$ Oral Maxillofac Implants. 1994;9(6):711-8.

18. Gunne J, Astrand P, Lindh T, Borg K, Olsson M. Tooth-implant and implant supported fixed partial dentures: A 10-year report. Int J Prosthodont. 1999;12(3):216-21.

PMid: 10635188

19. McGlumphy EA, Campagni WV, Peterson LJ. A comparison of the stress transfer characteristics of a dental implant with a rigid or a resilient internal element. J Prosthet Dent. 1989;62(5):58693. https://doi.org/10.1016/0022-3913(89)90085-1 PMid:2691664

20. Maeda MY, Walmsley AD. Implant Dentistry with New Generation Magnetic Attachments. Chicago, IL, USA: Quintessence; 2005.

21. Lobene R, Weatherford T, Ross W, Lamm R, Menaker L. A modified gingival index for use in clinical trials. Clin Prev Dent. 1986;8(1):5-7.

PMid:3485495

22. Tsang $A$, Sweet $D$, Wood RE. Potential for fraudulent use on digital radiography. J Am Dent Assoc. 1999;130(9):1325-9. PMid:10492539

23. Goga R, Chandler NP, Love RM. Clarity and diagnostic quality of digitized conventional intraoral radiographs. Dentomaxillofac Radiol. 2004;33(2):103-7. https://doi.org/10.1259/ dmfr/13010370

PMid: 15314002

24. Glavind L, Loe H. Errors in the clinical assessment of periodontal destruction. J Periodont Res. 1967;2(3):180-8.

PMid:4237475

25. Atassi F, Almas K. A comparative study of two pressure sensitive manual periodontal probes. Saudi Dental J. 1997;9:139-43.

26. Abdel Hakim AA. Clinical and Radiographic Evaluation of Tooth Implant Combination Supporting Telescopic Prosthesis in
Cases of Remaining Mandibular Cuspids, Ph. D. Thesis. Egypt: Removable Prosthodontics Department, Faculty of Dentistry, Alexandria University; 2001.

27. Sadowsky SJ. Mandibular implant-retained overdentures: A literature review. J Prosthet Dent. 2001;86(5):468-73. PMid: 11725274

28. Chee WW, Cho GC. A rationale for not connecting implants to natural teeth. J Prosthodont. 1997;6(1):7-10.

PMid:9497763

29. Olsson M, Gunne J, Astrand P, Borg K. Bridges supported by free-standing implants versus bridges supported by tooth and implant. A five-year prospective study. Clin Oral Implants Res. 1995;6(2):114-21. https://doi. org/10.1034/j.1600-0501.1995.060207.x PMid:7578781

30. Gotfredsen K, Holm B. Implant-supported mandibular overdentures retained with a ball or bar attachment: A randomized prospective 5-year study. Int $\mathrm{J}$ Prosthodont. 2000;13(2):125-30.

PMid: 11203620

31. Zinner I, Stanley A, Curtis E, Francis V. Multiple implants for first molar prosthodontics. J Prosthod. 2005;5(3):158-65.

PMid:9028219

32. Lundborg G, Branemark PI, Rosen B. Osseointegrated thumb prostheses: A concept for fixation of digit prosthetic devices. J Hand Surg Am. 1996;21(2):216-21.

PMid:8683049

33. Aydin C, Nemli SK, Yilmaz H. Esthetic, functional, and prosthetic outcomes with implant-retained finger prostheses. Prosthet Orthot Int. 2013;37(2):168-74. https://doi. org/10.1177/0309364612449850

PMid:22833519

34. Jorgensen EB, Bochet G, Grundman M, Borgis S. Aesthetic considerations for the treatment of partially edentulous patients with removable dentures. J Pract Periodont Aesthet Dent. 2000;12(8):765-72.

PMid: 11404872

35. Kenney R, Richards MW. Photoelastic stress patterns produced by implant-retained overdentures. J Prosthet Dent. 1998;80(5):559-64. https://doi.org/10.1016/ s0022-3913(98)70032-0

PMid:9813806

36. Machado AC, Cardoso L, Brandt WC, Henriques GE, de Arruda Nóbilo MA. Photoelastic analysis of the distribution of stress in different systems of overdentures on osseous-integrated implants. J Craniofac Surg. 2011;22(6):2332-6. https://doi. org/10.1097/scs.0b013e318232a791

PMid:22134270

37. Hunter FM, Martin ND, Godfry K, Hume WR. Comparison of clinical data derived with conventional probes versus a pressure sensitive, disposable periodontal probe. J Dent Res. 1992;71:587.

38. Augustin MM, Joke D, Bourleyi SI, Shenda LP, Fidele NB, Gabriel BB, et al. Risks factors of caries and periodontal diseases in the patients, after 5 years usea partial removable denture. Open J Stomatol. 2016;6(8):185-92. https://doi. org/10.4236/ojst.2016.68024

39. Alam-Eldeen H. The Effect of Attachments Versus Telescopic Crowns in Tooth-implant Supported Kennedy Class I Partial Denture on the Abutments. Cairo, Egypt: Cairo University; 2011.

40. Saleh A. Abutment Tissue Health as Related to Clasp Design in Implant Assisted Mandibular Distal Extension Removable Partial Overdentures. Mansoura, Egypt: Mansoura University; 2014. 
41. Ten Cate AR. Oral Histology Development, Structure and Function. $4^{\text {th }}$ ed. St. Louis, Toronto, London: CV Mosby Co; 1994. p. 111.

42. Brill N, Tryde G, Stoltze K, El Ghamarawy E. Ecologic changes in the oral cavity caused by removable partial dentures. J Prosthet Dent. 1977;38(2):138. https://doi. org/10.1016/0022-3913(77)90278-5

PMid:268426

43. Nishimura K, Itoh T, Takaki K, Hosokawa R, Naito T, Yokota M. Periodontal parameters of osseointegrated dental implants. A 4-year controlled follow-up study. Clin Oral Implants Res. 1997;8(4):272-8. https://doi. org/10.1034/j.1600-0501.1997.080404.x PMid:9586473

44. Quirynen M, van Steenberghe D, Jacobs R, Schotte A, Darius $P$. The reliability of pocket probing around screw-type implants. Clin Oral Implants Res. 1991;2(4):186-92. https://doi. org/10.1034/j.1600-0501.1991.020405.x PMid:8597621

45. Spiekermann H, Jansen VK, Richter EJ. A 10-year follow-up study of IMZ and TPS implants in the edentulous mandible using bar-retained overdentures. Int J Oral Maxillofac Implants. 1995;10(2):231-43. https://doi.org/10.11607/jomi.3222

PMid: 7744443

46. Brudivik JS. Advanced Removable Partial Denture. $1^{\text {st }}$ ed Illinois: Quintessence; 1999. p. 153-9.

47. Lacerda TS, Laganá DC, González-Lima R, Zanetti AL. Contribution to the planning of implant-supported RPD in the distal region. RPG Rev Pós Grad. 2005;12(3):293-300.

48. ELsyad MA, Habib AA. Implant-supported versus implantretained distal extension mandibular partial overdentures and residual ridge resorption: A 5-year retrospective radiographic study in men. Int J Prosthodont. 2011;24(4):306-13. https://doi. org/10.1111/jopr.12780 PMid:21716967

49. Mitrani R, Brudvik SJ, Phillips KM. Posteriorn implants for distal extension removable prostheses: A retrospective study. Int $J$ Periodontics Restorative Dent. 2003;23(4):353-9. https://doi. org/10.1111/j.1365-2842.2009.02044.x

PMid:12956479 